Journal of Earth Sciences and Geotechnical Engineering, Vol. 11, No. 2, 2021, 1-13 ISSN: $1792-9040$ (print version), $1792-9660$ (online)

https://doi.org/10.47260/jesge/1121

Scientific Press International Limited

\title{
Topography and Climate of Iraq
}

\author{
Nadhir Al-Ansari ${ }^{1}$
}

\begin{abstract}
Iraq is located between geographic coordinates $3300 \mathrm{~N}, 4400 \mathrm{E}$, and occupies a total area of 437,072 square kilometers. Land forms 432,162 square kilometers while water forms 4,910 square kilometers of the total area. Iraq is bordered by Turkey from the north. Iran from the east, Syria and Syria from the west, and Saudi Arabia and Kuwait from the south. Iraq can be divided according to the nature of the land terrain into 4 regions (Mountain Region, Plateau and Hills Regions, The Mesopotamian plain and Jazera and Western Plateau). The climate is mainly of continental, subtropical semi-arid type. The mountain region is of Mediterranean climate. In general, rainfall occurs from December to February or November to April in the mountain region. During winter the average daily temperature is about $16^{\circ} \mathrm{C}$ dropping at night to $2^{\circ} \mathrm{C}$ with possibility of frost. In summer however, it is very hot with an average temperature of over $45^{\circ} \mathrm{C}$ during July and August dropping to $25^{\circ} \mathrm{C}$ at night.
\end{abstract}

Keywords: Topography, Climate, Iraq.

${ }^{1}$ Lulea University of Technology, Lulea, Sweden.

Article Info: Received: October 27, 2020. Revised: November 1, 2020.

Published online: November 15, 2020. 


\section{Introduction}

Iraq is located between geographic coordinates 3300 N, $4400 \mathrm{E}$ (see Figure 1), and occupies a total area of 437,072 square kilometers. Land forms 432,162 square kilometers while water forms 4,910 square kilometers of the total area. Iraq is bordered by Turkey from the north, $352 \mathrm{~km}$, Iran from the east, $1,458 \mathrm{~km}$, Syria and Syria from the west, $605 \mathrm{~km}$ and $181 \mathrm{~km}$, respectively and Saudi Arabia and Kuwait from the south, $814 \mathrm{~km}$ and $240 \mathrm{~km}$, respectively.

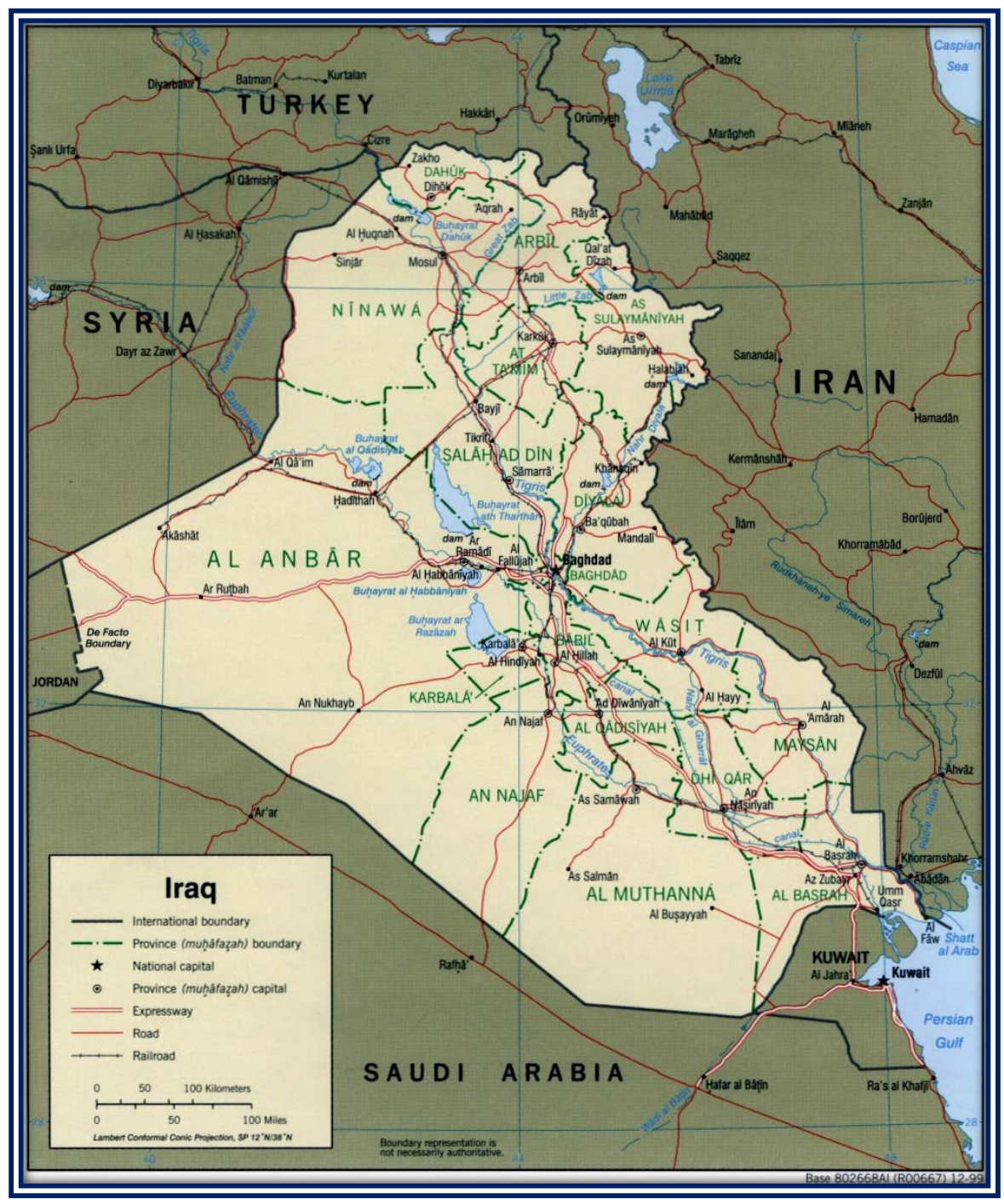

Figure 1: General map of Iraq. 
The total population in Iraq is about 40,000,000. The majority are Arabs (75-70\%) followed by Kurds (15-20\%), Turkomans, Assyrian and others (5\%) (Figures 2 and 3 ). At least $95 \%$ of the population is Muslims with minority of other religions, e.g. Christians and Sabia. The official language is Arabic and Kurdish. Kurdish language is the language used in the Kurdish region. Other languages, e.g. Assyrian and Armenian, are locally used but not official. Iraq is composed of 18 Governorates (Figure 4). They are Al Anbar, Al Basrah, Al Muthana, Al Qadisiyah, Al Najaf, Al Sulaymaniyah, Al Tamim, Babil, Baghdad, DahEU, Dhi Qar, Diyala, Irbil, Karbalah, Maysan, Ninawa, Salah ad Din and Wasit. The legislature is National Assembly of 250 members elected by popular vote for four years.

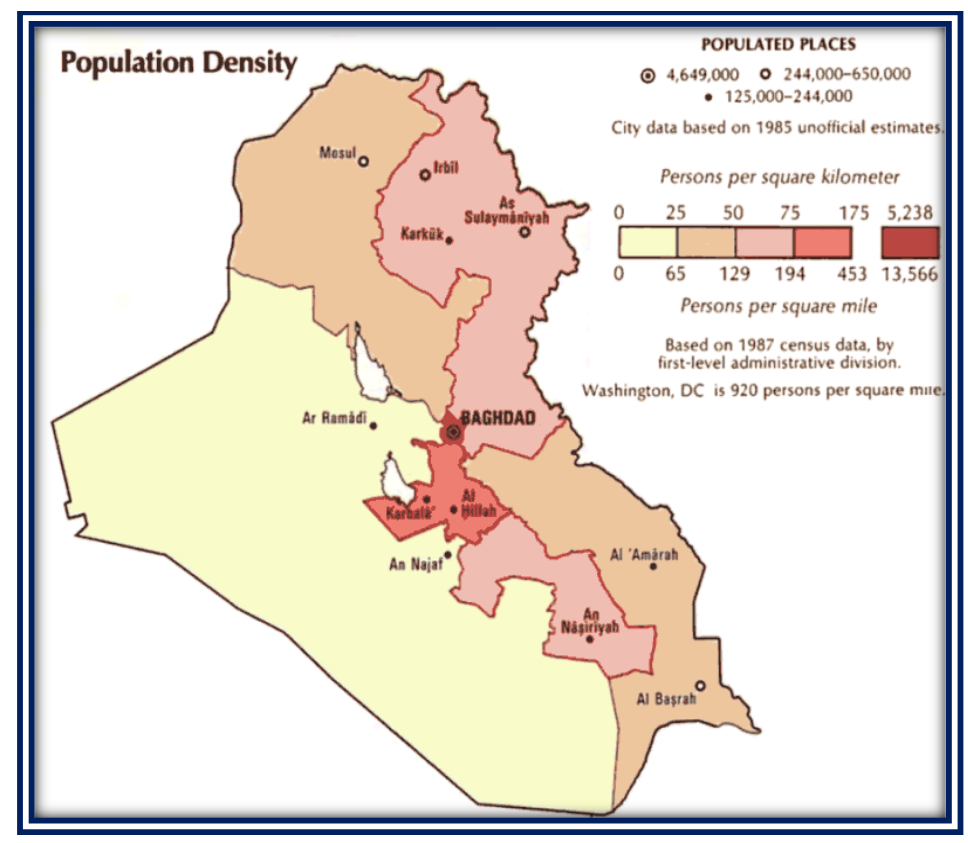

Figure 2: Population density in Iraq. 


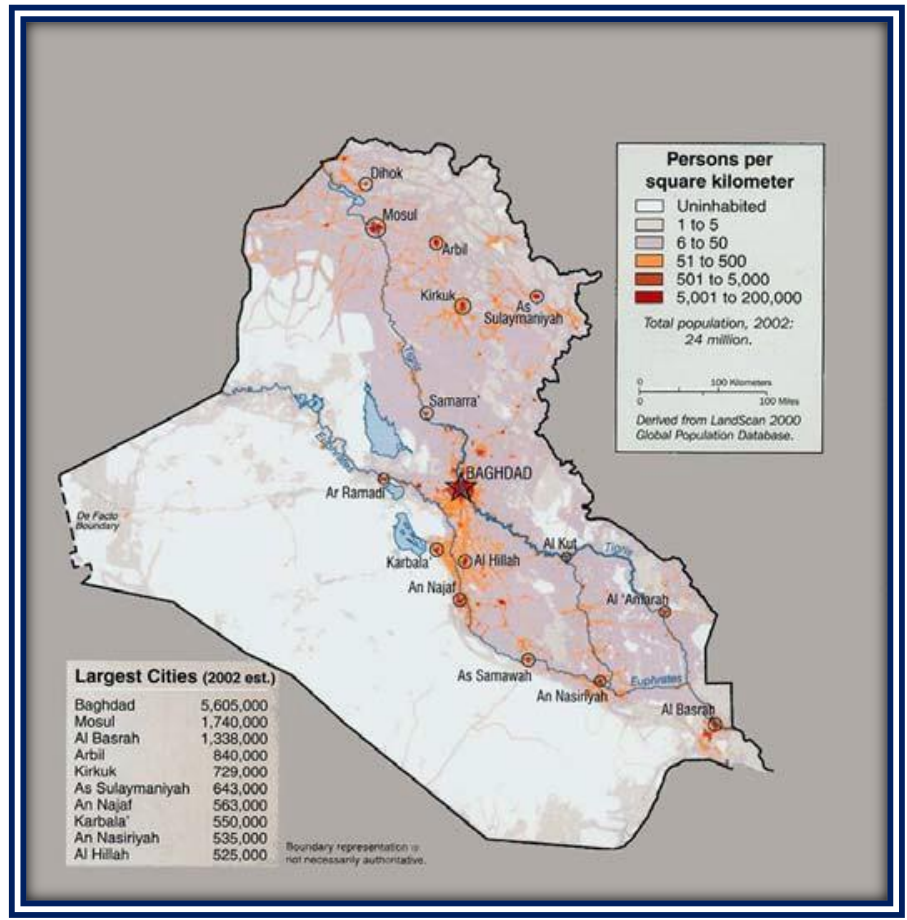

Figure 3: Population in major cities of Iraq.

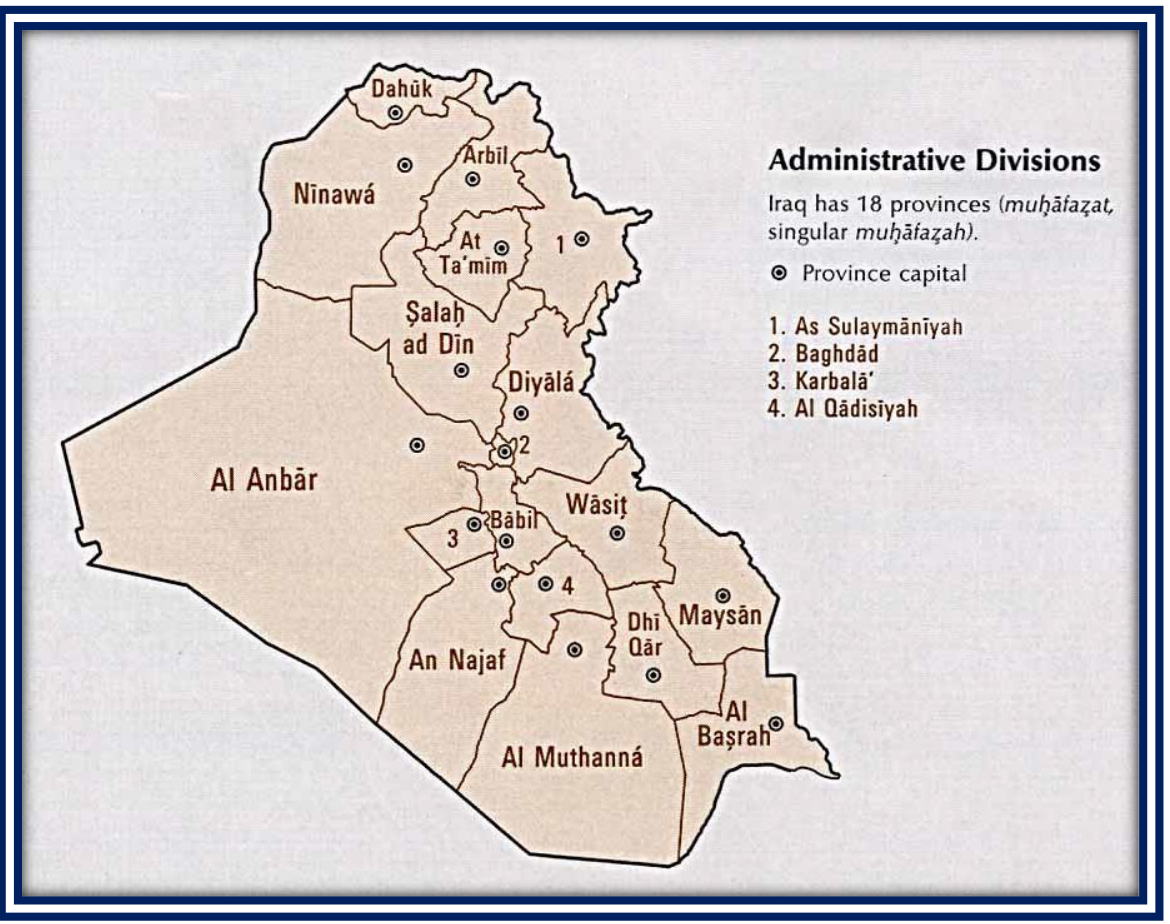

Figure 4: Governorates of Iraq. 
Iraq was part of the Ottoman Empire, and was occupied by Britain during World War I. In 1920 it was declared a League of Nations mandate under EU administration. Iraq attained independence as kingdom in 1932. On 14 July, 1958, Iraq was proclaimed as a republic.

\subsection{Topography}

Iraq can be divided according to the nature of the land terrain into 4 regions (Figures 5, 6 and 7) as follows (Al-Ansari, 1988, 2005, 2013; Al-Ansari et.al., 1981; AlAnsari and Knutsson, 2011).

\subsubsection{Mountain Region}

This region occupies 5\% of the total area of Iraq, Figure 7, restricted at the north and north eastern part of the country. This region is part of Taurus-Zagrus mountain range. The altitude ranges between $3000-1000 \mathrm{~m}$ above sea level. At the north, the mountain range extends from the west toward the east while it extends from the North West towards the southeast at the northeastern part of Iraq at the Iraq-Iran border. The average annual rainfall within this region is of the order of $1000 \mathrm{~mm}$ with snow covering the peaks of the mountains. This part of Iraq is considered to be the most important part as a source for its water resources. 


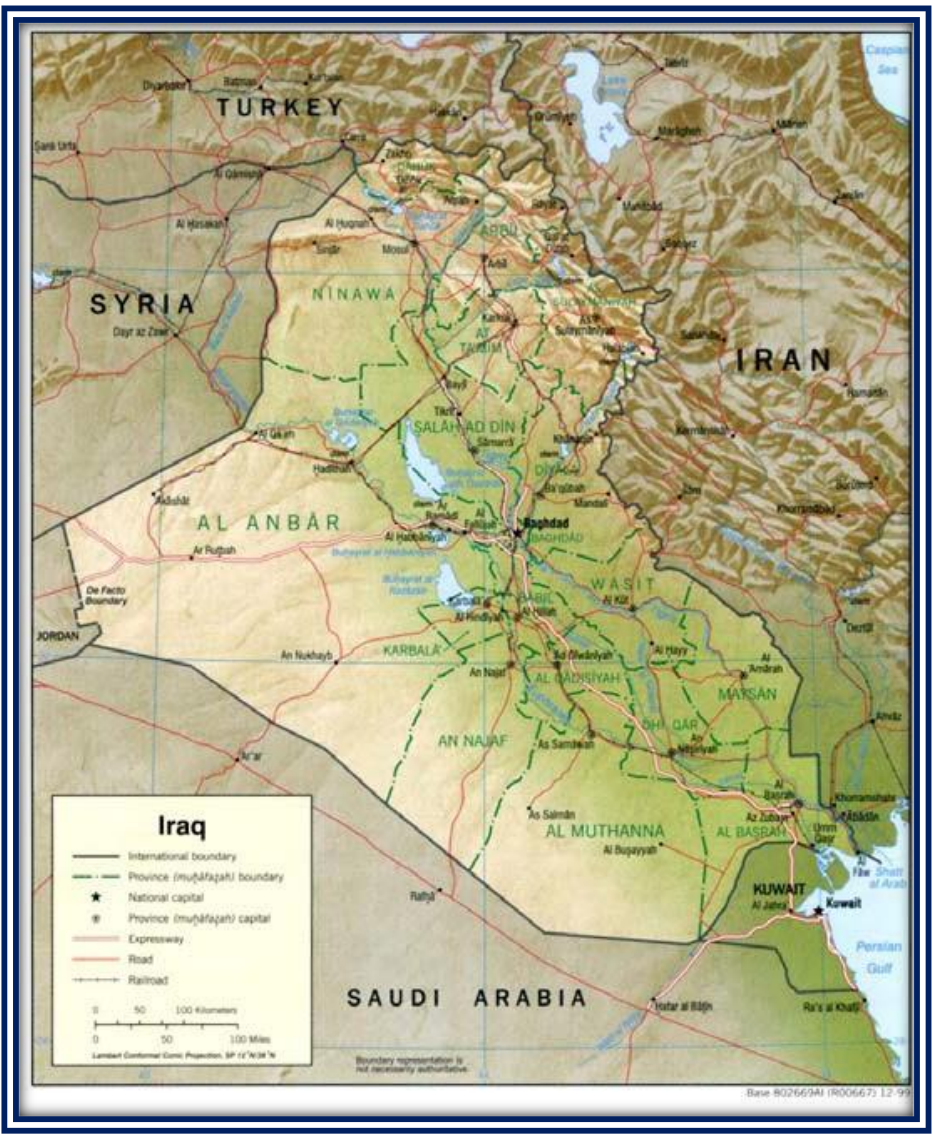

Figure 5: Physiography of Iraq.

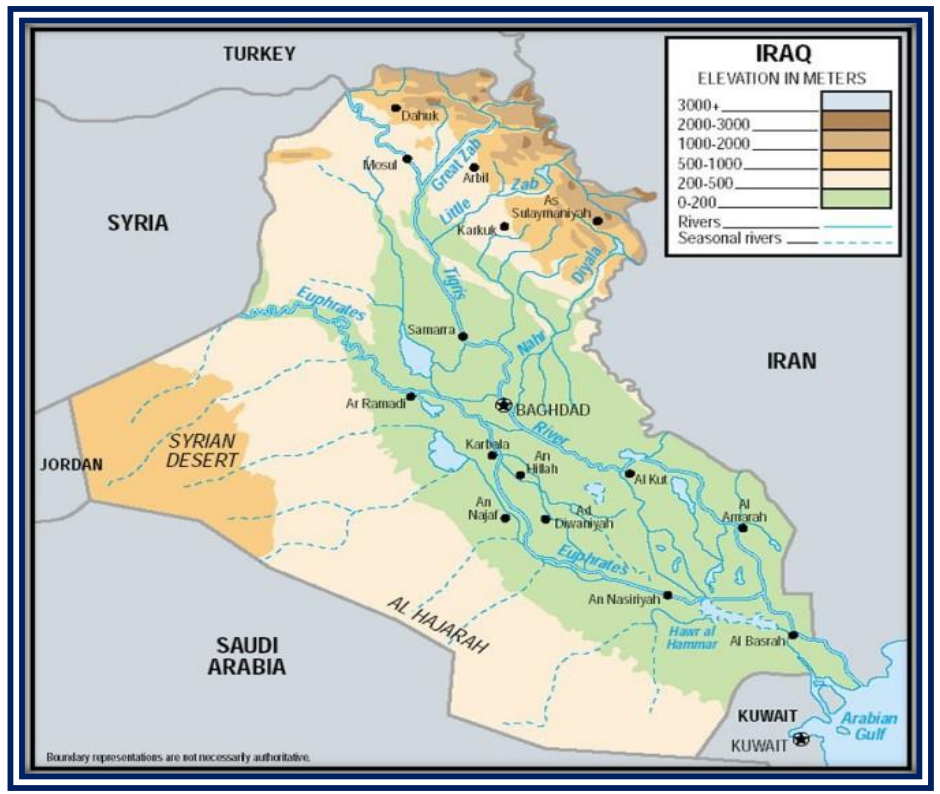

Figure 6: Elevation of land in Iraq. 


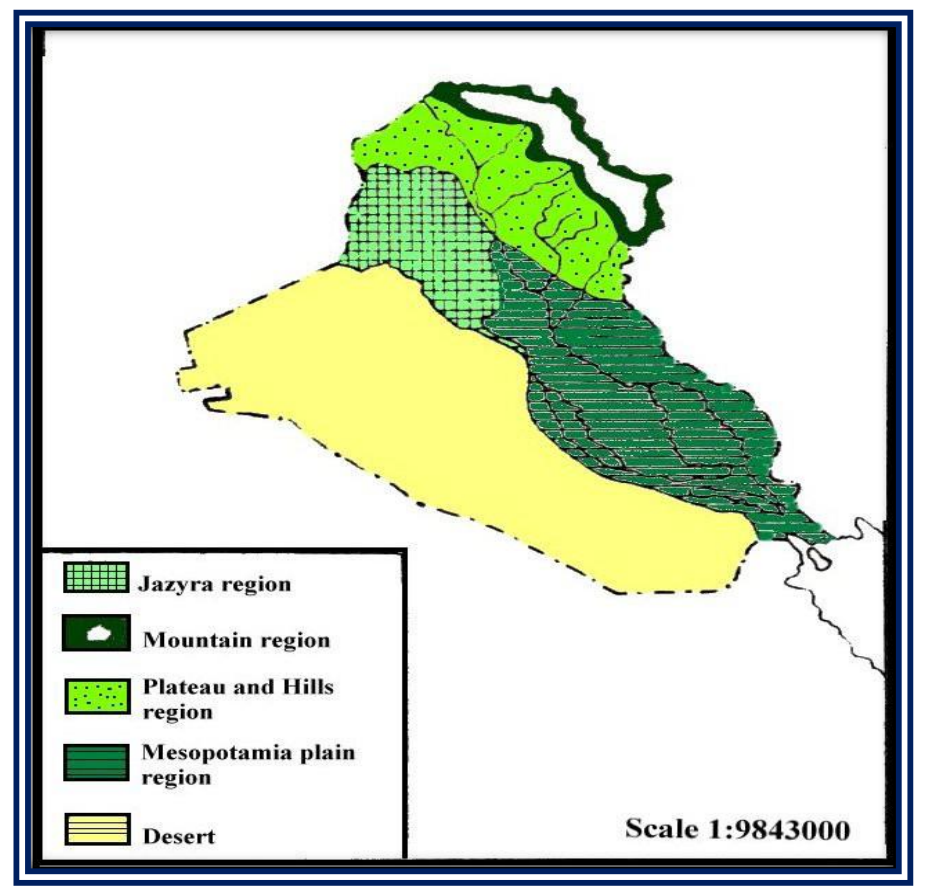

Figure 7: Topographic division of Iraq.

Deep valleys are a dominating feature of this region with small plain areas between the mountain ranges. Important tributaries run through the plain areas to join the River Tigris (e.g. Greater Zab, Lower Zab and Khaboor). The most important mountains of this area are: Hesarroast, Permam, Sifeen, Azmer, Horman and Pengiween.

\subsubsection{Plateau and Hills Regions}

The altitude of the plateau in this area is of the order of 200 to $1000 \mathrm{~m}$ above sea level. This area represents $15 \%$ of the total area of Iraq (Figure 7). This region is bordered by the mountainous region at the north and the Mesopotamian plain from the south. The most important mountain ranges of this region in Sinjar, Ibrahiem, Bashiqa, Makhul and Hemrien.

The average annual rainfall of this region ranges from 200 to $500 \mathrm{~mm}$. Thus, large number of dry valleys is noticed in this area. All the tributaries of the River Tigris run through this area where the main dams are constructed, e.g. Dokan, Derbendikhan, Hemrien and Mosal Dams. The dams were constructed in this region due to the fact that mountain ranges come close to the main courses of the rivers enforcing the rivers to have narrow valleys. Such conditions are the best areas for construction of dams. 


\subsubsection{The Mesopotamian plain}

This area is restricted between the main two Rivers, Tigris and Euphrates. It occupies $20 \%$ of the total area of Iraq. This plain extends from north at Samara, on the Tigris, to Hit, on the Euphrates, J0048Ntoward the Gulf in the south, Figure 7. The area is characterized by its very gentle slope from the north towards the south. The average annual rainfall is of the order of $250 \mathrm{~mm}$. The agricultural activities depend on irrigation canals from the Tigris and Euphrates.

\subsubsection{Jazera and Western Plateau}

This area occupies $60 \%$ of the total area of Iraq, Figure 7. The altitudes might reach $900 \mathrm{~m}$ above sea level in certain areas. The slop of the Western plateaus is from the west toward the east where it approaches the River Euphrates. This plateau is characterized by large dry valleys. Horan valley is the most important one with a total length of $485 \mathrm{~km}$, while Tharthar valley is the most important within the Jazera area with a total length of $300 \mathrm{~km}$.

This region is characterized by its low annual rainfall which does not exceed $200 \mathrm{~mm}$ per year. For this reason, small dams had been constructed on the valleys of the Western Desert for harvesting water during rain seasons to be used in summer.

\subsection{Climate}

The climate is mainly of continental, subtropical semi-arid type. The mountain region is of Mediterranean climate. In general, rainfall occurs from December to February or November to April in the mountain region. During winter the average daily temperature is about $16^{\circ} \mathrm{C}$ dropping at night to $2^{\circ} \mathrm{C}$ with possibility of frost. In summer however, it is very hot with an average temperature of over $45^{\circ} \mathrm{C}$ during July and August dropping to $25^{\circ} \mathrm{C}$ at night (Al-Ansari, 1988, 2005, 2013; Al-Ansari et.al., 1981; Al-Ansari and Knutsson, 2011).

\subsubsection{Rainfall}

The annual rainfall in Iraq varies where it reaches $150 \mathrm{~mm}$ within the western desert, more than $1000 \mathrm{~mm}$ within the mountains at the north to about $200 \mathrm{~mm}$ at the eastern part of the country, Figure 8 . The overall average annual rainfall is of the order of $213 \mathrm{~mm}$ per year. The rainy season begins in October and ends in April. It is evident from Figure 8 and Table 1 that annual rainfall increase from southwest towards northeast due to topographic effect. Furthermore, it can be noticed that individual topographic regions are characterized by their own climatic factors and rainfall values. It should be mentioned however, that despite the local climatic differences, all the regions have similar overall climatic features. This is due to the fact that Iraq as a whole is affected by its geographic position. When rainfall is used as a base to classify the climate, two seasons can be noticed:

Dry season starting in April to September. Wet season starting in October to May. It can be stated that October represent the transition period from dry to wet seasons while May representing the transition from humid to dry season. 


\subsubsection{Temperature, Sunshine and Evaporation}

The range of daily temperature varies greatly between day and night reflecting the continental climate. In addition, the trend in temperature increase is exactly the opposite to that of the rainfall's trend, where it increases from northeast toward southwest, Table 2 . The maximum daily temperature during dry season could rise to over $50^{\circ} \mathrm{C}$, while the minimum temperature during the wet season could reach $14^{\circ} \mathrm{C}$ in Rutba and about $8^{\circ} \mathrm{C}$ in Baghdad (Figures 9 and 10). It can also be noticed at the south, in Basrah in particular, that the temperature during summer is less than that of the surrounding areas due to high humidity resulting from being near to the Gulf.

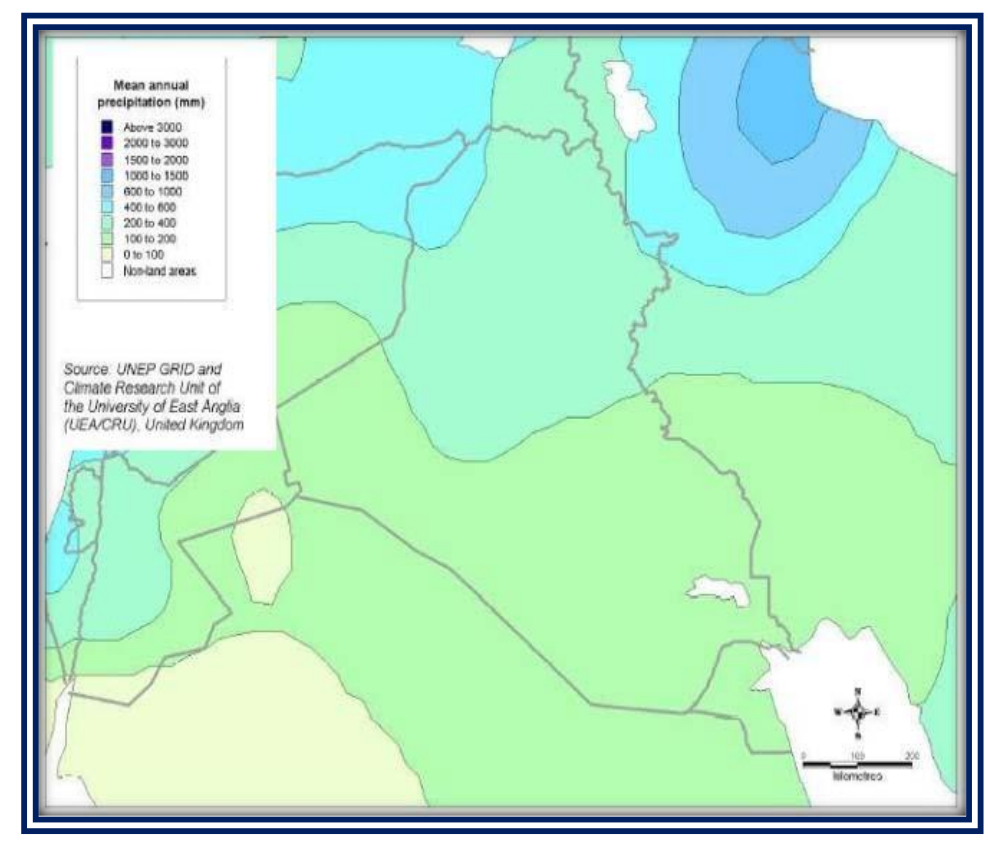

Figure 8: Mean annual precipitation in Iraq. 
Table 1: Average annual rainfall in some major stations in Iraq

\begin{tabular}{|c|c|c|c|c|}
\hline \multicolumn{7}{|c|}{ (period of record 35 years). } \\
\hline Month & Mosul & Baghdad & Rutbuh & Basrah \\
\hline Oct. & 8.7 & 3.1 & 4.014 .0 & 0.8 \\
\hline Nov. & 36.8 & 16.0 & 16.4 & 20.5 \\
\hline Dec. & 63.4 & 24.3 & 14.2 & 30.9 \\
\hline Jan. & 68.1 & 36.2 & 14.4 & 25.2 \\
\hline Feb. & 65.0 & 25.9 & 17.3 & 13.9 \\
\hline Mar. & 70.0 & 26.6 & 21.4 & 19.2 \\
\hline Apr. & 54.4 & 22.0 & 12.4 & 20.5 \\
\hline May & 23.0 & 7.9 & 0.0 & 7.2 \\
\hline June & 0.0 & 0.0 & 0.0 & 0.0 \\
\hline July & 0.0 & 0.0 & 0.0 & 0.0 \\
\hline Aug. & 0.0 & 0.0 & 0.0 & 0.0 \\
\hline Sep. & 0.0 & 0.0 & 0.0 & 0.0 \\
\hline Total & $\mathbf{4 0 0 . 2}$ & $\mathbf{1 5 2 . 0}$ & $\mathbf{1 1 5 . 1}$ & $\mathbf{1 3 8 . 2}$ \\
\hline
\end{tabular}

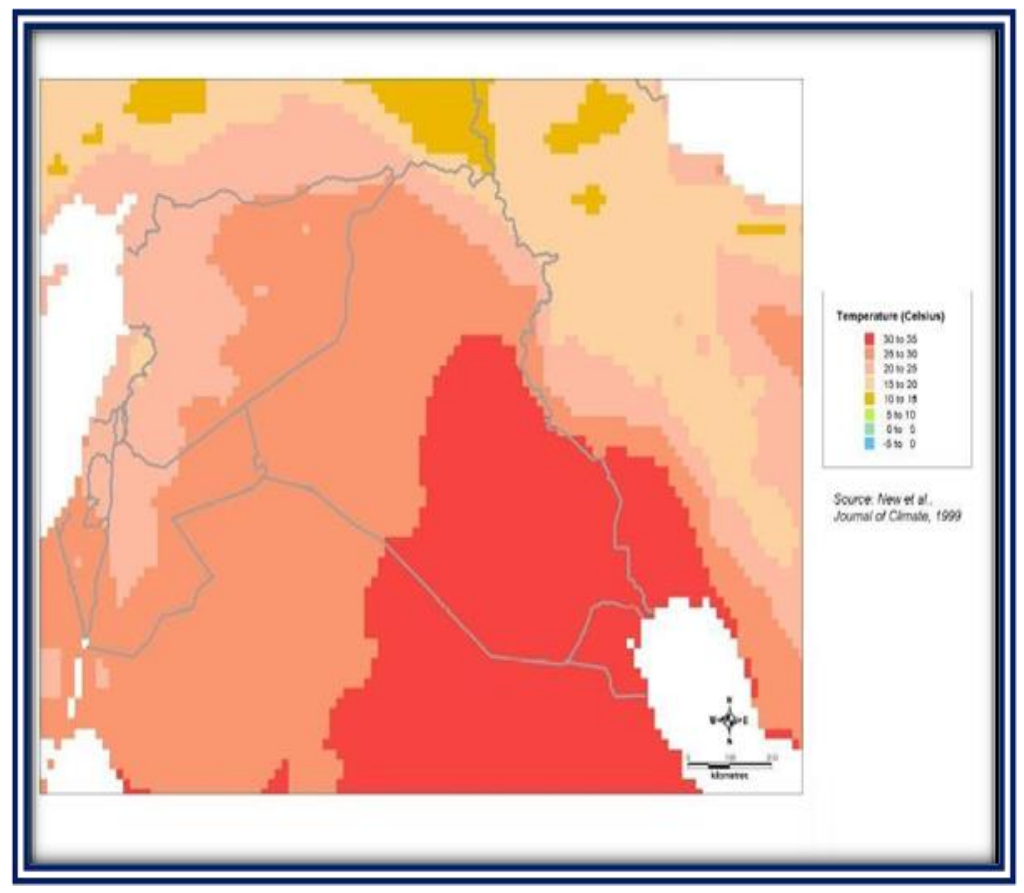

Figure 9: Mean maximum Temperature in Iraq. 


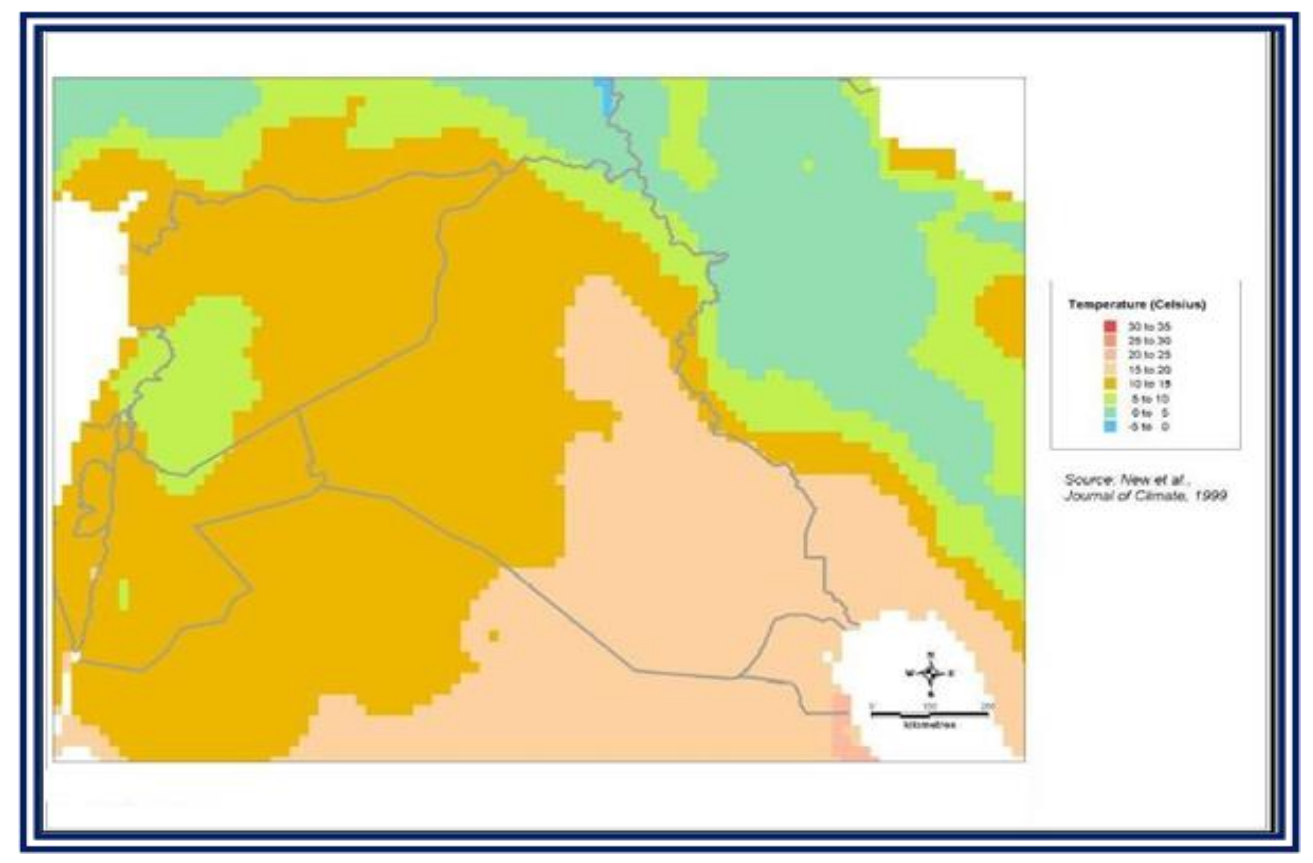

Figure 10: Mean minimum Temperature in Iraq.

Table 2: Temperature and sunshine duration at three major station in Iraq.

\begin{tabular}{|c|c|c|c|c|c|c|c|c|c|}
\hline \multirow[b]{2}{*}{ Month } & \multicolumn{3}{|c|}{ Mosul } & \multicolumn{3}{|c|}{ Baghdad } & \multicolumn{3}{|c|}{ Basrah } \\
\hline & Temp & $\begin{array}{c}\mathrm{Cal} / \mathrm{cm}^{2} \\
\text { day }\end{array}$ & $\begin{array}{c}\text { Sunrise } \\
\text { duration \% }\end{array}$ & Temp & $\begin{array}{c}\mathrm{Cal} / \mathrm{cm}^{2} \\
\text { day }\end{array}$ & $\begin{array}{c}\text { Sunrise } \\
\text { duration \% }\end{array}$ & Temp & $\begin{array}{c}\mathrm{Cal} / \mathrm{cm}^{2} \\
\text { day }\end{array}$ & $\begin{array}{c}\text { Sunrise } \\
\text { duration \% }\end{array}$ \\
\hline Oct. & 25.0 & 266 & 74 & 24.6 & 418 & 79 & 25.9 & 483 & 83 \\
\hline Nov. & 18.5 & 251 & 49 & 17.6 & 323 & 70 & 19.3 & 362 & 71 \\
\hline Dec. & 8.3 & 206 & 49 & 11.0 & 261 & 63 & 12.6 & 318 & 69 \\
\hline Jan. & 7.7 & 253 & 46 & 10.0 & 298 & 64 & 12.4 & 260 & 70 \\
\hline Feb. & 8.7 & 320 & 54 & 12.3 & 357 & 68 & 14.6 & 450 & 72 \\
\hline Mar. & 12.3 & 385 & 56 & 16.3 & 454 & 65 & 18.7 & 535 & 69 \\
\hline Apr. & 17.4 & 476 & 62 & 21.9 & 534 & 67 & 42.1 & 618 & 66 \\
\hline May & 24.0 & 562 & 72 & 28.9 & 599 & 72 & 29.7 & 621 & 70 \\
\hline June & 30.5 & 653 & 87 & 33.0 & 651 & 85 & 22.7 & 642 & 78 \\
\hline July & 34.0 & 616 & 89 & 34.0 & 645 & 83 & 34.0 & 628 & 76 \\
\hline Aug. & 33.0 & 565 & 90 & 34.4 & 598 & 87 & 33.6 & 635 & 81 \\
\hline Sep. & 27.7 & 513 & 87 & 30.6 & 540 & 87 & 30.6 & 596 & 88 \\
\hline
\end{tabular}

$$
\%=\frac{\text { ActionSunriseHours }}{\text { TotalSunriseHours }} x 100
$$


Sunshine records, Table 2, indicate that during dry period, May - September, the average is more than $500 \mathrm{cal} / \mathrm{cm}^{2} /$ day while it is below this value during wet season (October - April). Meteorological record was used to calculate the evaporation and evapotranspiration values using penman method. The results, Figure 11, show that the overall average evaporation and evapotranspiration is of the order of $1900 \mathrm{~mm}$ per year. Furthermore, the values show an increasing trend similar to that of the temperature increasing from northeast towards the southwest.

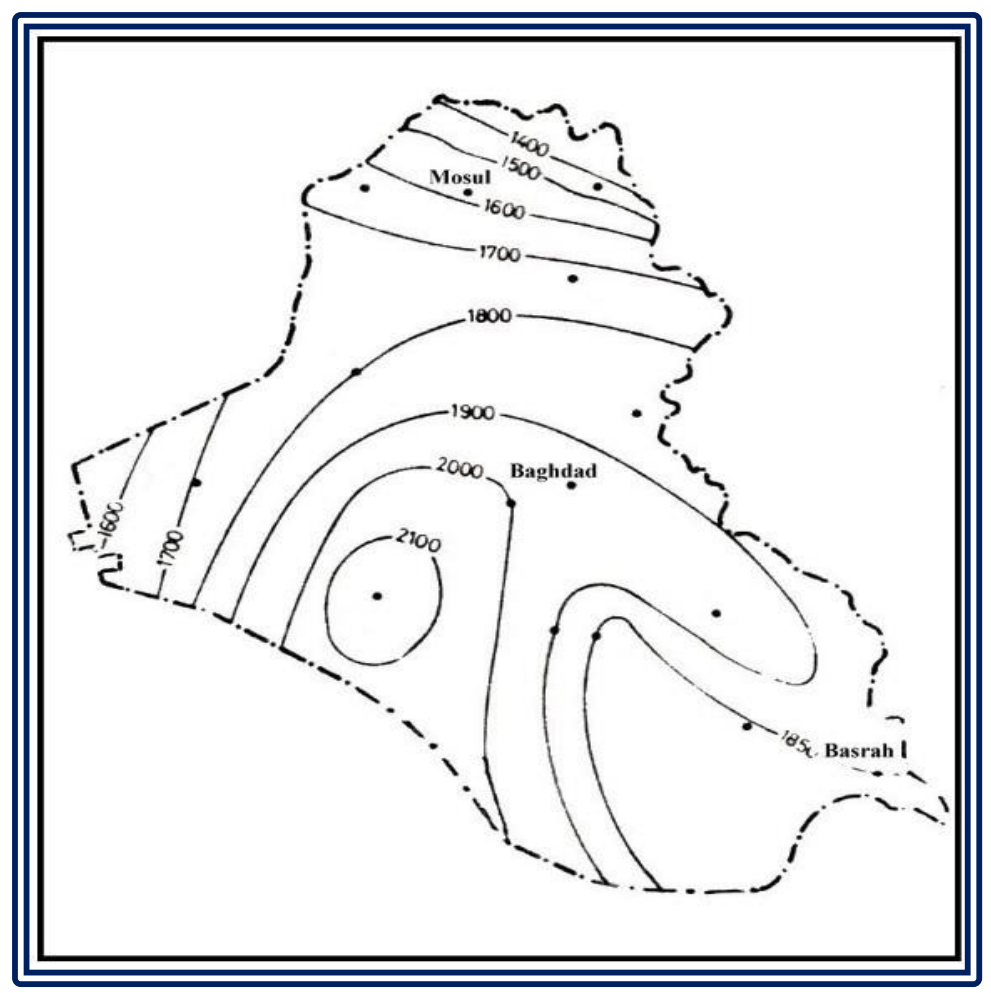

Figure 11: Evaporation counters of Iraq. 


\section{References}

[1] Al-Ansari, N. A. (1988). Water Resources in the Arab Countries: Problems and Possible Solutions. UNESCO International conference on Water: A Looming Crisis, Paris, pp. 367-376.

[2] Al-Ansari, N. A. (2005). Applied Surface Hydrology. Al-Bayt University Publication.

[3] Al-Ansari, N.A. (2013). Management of Water Resources in Iraq: Perspectives and Prognoses, J. Engineering, Vol.5, 8, pp.667-684.

[4] Al-Ansari, N. A., Assaid, H. I. and Salim, V. N. (1981). Water Resources in Iraq, J. Geological Society-Iraq, Vol.15, pp.35-42.

[5] Al-Ansari, N. A. and Knutsson, S. (2011). Toward Prudent Management of Water Resources in Iraq. J. Advanced Science and Engineering Research, Vol. 1, pp.53-67. 